\title{
Histomorphology of Salivary Glands after Ligature and Reconstruction of Common Carotid Artery in Rabbits
}

\author{
Kaspars Stamers*, Mara Pilmane**, Laila Feldmane ${ }^{* * *}$, Kalvis Pastars ${ }^{* * * *}$, Nonna Tomisheva ${ }^{* * * *}$, Andrejs Skagers* \\ *Department of Oral and Maxillofacial Surgery, Riga Stradins University, Latvia \\ **Institute of Anatomy and Anthropology, Riga Stradins University, Latvia \\ ***Department of Pathology, Riga Stradins University, Latvia \\ $* * * *$ Department of Reconstructive and Plastic Surgery, Austrumu Clinical University Hospital, Riga, Latvia
}

\begin{abstract}
Summary
Introduction. In occlusive diseases of carotid arteries may be involved salivary glands which play important role in oral and general homeostasis.

Aim of the study. The purpose of this study was histomorphological evaluation of rabbit's salivary glands after regional reduction af arterial circulation and reconstruction of ligated common carotid arteries comparing with normal histological sight.

Materials and methods. The experiments were authorized by the Animal Ethics Committee of the Latvian Food and Veterinary Service. 20 male Californian rabbits weighing approximately $3 \mathrm{~kg}$ were used. Under intravenous general anesthesia and local anesthesia the ligature of a. carotis communis dextra was done. After 28 days 10 rabbits were sacrificed and samples were taken from all major salivary glands and histological measured acinar dimensions and acinar epithelial cell.

For rest 10 rabbits under the general anesthesia were performed revascularization of a. carotis communis dextra. After 28 days the rabbits were sacrificed with intrapulmonal injection of T61. The acini dimensions and acinar epithelial cell diameter in microns in all glands were measured except buccal glands were measured.
\end{abstract}

Results. In ischemic conditions all glands react with decrease of acinar epithelial cell diameter and also diametr of functional unit of salivary gland.After revascularisation reestablishment of acini and secretory epithelial cells was observed.

Conclusions. Rabbit's salivary glands have potential to recovery in diminished after ligation of ipsilateral common carotid artery size of acini and secretory epithelium after 4 week ischemia if the blood supply is reestabilished.

Key words: salivary glands; histology; carotid artery ligature; reconstruction.

\section{INTRODUCTION}

Salivary secretion is crucial in maintenance of oral health and play important role in prevention of dental caries also in healing of extraction wounds $(6,10)$.

Age related alterations of normal structure of salivary glands includes decrease of parenchimatous structures and increase of stromal, ductal part and fat tissue content (16). On data from human necropsies it was supposed that increasing level of degenerative vascular disease through ischaemia has some causal relation to the aging atrophy of salivary gland parenchyma.Significant sex diferences in aging changes of human salivary glands were not present (20). Different results were obtained on secretory function in young adult and aged male and female rats. No significant alterations in submandibular gland salivary flow rate or the concentrations of total protein, $\mathrm{Na}^{+}, \mathrm{K}^{+}$and neutral sugar in the secreted saliva were observed between different aged animals. Significant sex diferences in salivary flow rate and total protein content were found in rats(22). Necrotic laesions of salivary glands as necrotizing sialometaplasia is regarded as result of compromised blood supply to the salivary gland usually by local trauma, some role has smoking $(1,3)$.

In experiment lobular necrosis of salivary glands was observed after ligating of vesels close to gland (22). The lobular configuration of necrosis is explained by the separate blood flow to each lobule. In experimental studies there are more data on histomorphological response of salivary glands to ligation of salivary ducts as vesels feeding salivary glands. We can't find any publication to compare histomorphology of salivary glands after ligation and reconstruction of feeding artery.

\section{AIM OF THE STUDY}

The aim of the study is to determain the influence of ischemia to salivary gland tissue and ability to recover after reestablishment of regional blood supply.

\section{MATERIALS AND METHODS}

The experiments were authorized by the Animal Ethics Committee of the Latvian Food and Veterinary Administration. Twenty male Californian rabbits weighing approximately $3 \mathrm{~kg}$ were used. Under intravenous general anesthesia with Diazepam $2 \mathrm{mg} / \mathrm{kg}$ and $5 \%$ Ketamin hydrochloride $15 \mathrm{mg} / \mathrm{kg}$ and local infiltration with $0.5 \%$ Lidocain solution $5 \mathrm{ml}$, the ligature of a. carotis communis dextra was performed with 4-0 silk and the wound was closed with Vicryl 5-0. After 28 days under general anesthesia 10 rabbits were sacrificed and samples were taken from all major salivary glands. Samples were fixated in 10\% neutral 
formalin solution, embedded in paraffin and prepared for staining with hematoxilin - eosin. In light microscope under magnification of 400 times were measured acini dimensions except buccal gland because of it irregular structure in microns and acinar epithelial cell diameter in microns.

For rest 10 rabbits under the same general anesthesia revascularization of a carotis communis dextra by endto-end anastomosis using Monosof 8-0 sutures and 6X magnification loups was performed. All rabbits survived and after 28 days were sacrificed with intrapulmonal injection of T61. Histological samples were taken and prepared for histological examination. After in the same manner in light microscope acini and secretory cell dimensions were measured.

\section{RESULTS}

Submandibular gland in the side of ligature presented decrease of secret granules in glandulocytes. It shows slight decreased diameter of acini mean 0.9 microns $(p<0.05)$ and secretory epithelial cells mean 0.7 microns $(\mathrm{p}<0.05)$ in side of ischemia comparing to control side (Fig. 1). Control side represented more mucous secretion type (Fig.7).

In parotid gland after ligature also was decrease of cell and acini diameter in test side, correspondingly acini mean 0.9 microns $(p<0.05)$ and secretory epithelial cells mean 0.2 microns $(p<0.05)$ (Fig.2). Parotid gland also showed intersticial tissues enhance and manifest of glandular lipomatosis more than in control glands (Fig.8).

Buccal gland also showed decrease of cells in side of ligature mean in 1 micron $(\mathrm{p}<0.05)$ (Fig.3). The size of acini can not be measured because of irregular structure (Fig.9).

Submandibular gland after revascularization procedure showed morphometric parameters of glandular acini and acinar epithelial cells size more high as before artery ligation. Acini becomes in mean 0.1 micron bigger then in control side $(\mathrm{p}<0.05)$ but acinar epithelial cells in mean 0.6 microns bigger than control side (Fig.4).

Response of parotid gland after revascularization was the same; only in test side maintenance of lipomatosis was more than in control side. Acini reverted in mean 0.4 microns $(\mathrm{p}<0,05)$ and acinar epithelial cells 0.2 microns $(p<0.05)$ bigger then in control side(Fig.5).

Buccal gland histological changes also were in the same manner and acinar epithelial cells becomes bigger in mean 0.2microns ( $\mathrm{p}<0.05)$ (Fig.6).

\section{DISCUSSION}

In human medicine histopathological investigation of salivary glands besides another pathology is essential for differential diagnosis in cases of dry mouth syndrome more often due Sjögren's syndrome with replacement of parenchymatous secretory units by lymphocytic infiltration $(8,11)$. Age related changes in human salivary glands are studied on material of autopsies or biopsies. The main histological findings include fat infiltration between serous, mucous and myoepithelial cells in the intercalated and striated ducts $(18,24)$, replacement of functional parenchymatous cells by by fat and connective tissue also oncocytes $(25,19)$. Reduction of functionaly active parenchyma is explained due chronic obstruction of salivary ducts (21), acinar and ductal atrophy, ductal hyperplasia and dilatation (7). There are only some publications with data on intraglandular vascular changes as tortuosity of arteries and dilatation of veins(18), vascular congestion as result of atheromatous plaques and vascular obstructions (2) in human salivary glands with atrophic and degenerative changes. The vascularity network is regarded as critical to the functioning of the secretory acinar cells and the production of saliva , but it is difficult to detect in routine histological sections (26).

In experiment age-related changes of salivary glands were studied on rats and mouses $(13,14)$. Distribution pattern of blood vessels in mouse submandibular gland is in similar manner to that in humans and in such way histomorphological data obtained in experiment may be used in interpretation of human pathology. We can't find data about comparision of salivary gland morphology in human and rabbits. Rat and mouse salivary glands undergo severe degeneration if their blood supply via the main feeding artery is interrupted $(5,12,15)$. There is difference in ischemic damage severity in peripheral and central portions of salivary glands $(23,9)$. Three-dimensional evaluation of blood vessels using stereoscopic and scanning electron microscopy in mouse submandibular gland showed no communicating vesels between the gland proper and the capsula. It is suggested that the parenchymal cells surviving in the ischemic peripheral portion of the gland are nourished by permeation of tissue fluid contained in the capsula (17).

Our histomorphological data confirms ischemic damages of major salivary glands due ligation of regional feeding artery. No necrotic tissue changes were observed as are obtained in previous reports where ligation of feeding arteries was done more close to salivary gland and possibility of collateral compensation is less.All rabbit's major salivary glands showed decrease of secret granules in glandulocytes, diminished diameter of acinar epithelial cells and size of acini. Revascularisation due reconstruction of occluded common carotid artery resulted in restored functional morphology of ischemic salivary glands by increase in size of acinar epithelium and parenchymatous acini which showed to be bigger as on contralateral control side.

Histomorphological changes of salivary glands after occlusion of common carotid artery in experiment may have some consequences to explain salivary gland function in quiet common human pathology as are occlusive diseases of carotid arteries. 


\section{CONCLUSIONS}

1. After ligation of common carotid artery in rabbits ischemic changes as decrease in functional activity and size of major salivary gland acinar epithelial cells and size of acini occures.

2. Revascularisation by reconstruction of occluded common carotid artery provides increase in size of acinar epithelial cells and acini up to that on control collateral side.

\section{Conflict of interest: None}

\section{REFERENCES}

1. Aydin Ö, Yilmaz T, Özer F, Saraç S, Sökmensüer C, Necrotizing sialometaplasia of parotid gland: a possibility vasculitic cause // Int $\mathrm{J}$ Pediatric Otorhinolaryn, 2002; 64:171 - 174

2. Azevedo LR, Damante JH, Lara VS, Lauris JRP, Age related changes in human sublingual glands; a post mortem study // Arch Oral Biol, 2005; 50:565 574

3. Bodner L, Baum BJ, Submandibular gland secretory function in young adult and aged rats // Comparat Biochem Physiol A: Physiol, 1984; 77:235 - 238

4. Brannon RB, Fowler CB, Hartman KS, Necrotizing sialometaplasia: a clinicopathologic study of sixtynine cases and review of the literature // Oral Surg Oral Med Oral Pathol, 1991; 72:317 - 325

5. Burgess LK, Dardick I, Cell population changes during atrophy and regeneration of rat parotid gland // Oral Surg Oral Med Oral Patho Oral Radiol Endodont, 1998; 85:699 - 706

6. Dayan D, Bodner L, Horowitz I, Effect of salivary gland hypofunction on the healing of extraction wounds: A histomorphometric study in rats // J Oral Maxillofac Surg, 1992; 50:354 - 358

7. Drummond JR, Chisholm DM. A qualitative and quantitative study of the aging human labial salivary glands // Arch Oral Biol, 1984; 29:151 - 155

8. Fox RI, Robinson CA, Curd JG, Kozin F, Howell FV, Sjögren's syndrome. Proposed criteria for classification // Arthritis Rheum, 1986; 29:577 585

9. Fujisava Y, Aiyama S, Histochemical and chronological analysis of mouse submandibular gland parenchyma subjected to abrupt reperfusion // Histol Histopathol, 2003; 18:871 - 878

10. Gaubenstock LM, Dental caries and the secretory activity of human labial minor salivary glands // Arch Oral Biol, 1995; 40:525 - 528

11. Greenspan JS, Daniels TE, Talal N, Sylvester AR, The histopathology of Sjögren's syndrome in labial salivary gland biopsies // Oral Surg, 1974; 37:217 229

12. Hashimoto $\mathrm{T}$, Histopathological changes of rat palatine glands by ligation of palatine vesels // Meikai Univ. Dent. J. 1998; 27:33 - 41

13. Komesu MC, Lopes AR, Petenusci SO, Silva-Netto CR, Lopes OVP, Campos GM, Alteraçöes morfologicas da glândula submandibular do rato determinadas pelo envelhecimento // Rev Fac Odontol Ribeiräo Preto, 1986; 23:79-88

14. Liu P, Denny PA, Denny P. The effect of ageing on parenchymal cell populations in adult female mouse submandibulargland // Arch Oral Biol, 2000; 45:585592

15. Magoshi S, Histomorphological studies on the effects of ligation of the excretory duct and the main blood vessel on the rat submandibular gland: experimental development of necrotizing sialometaplasia // Meikai Univ. Dent. J. 1998; 27:20 - 32

16. Moreiraa Carla Ruffeil, Azevedob Luciana Reis, Laurisd JRP, Tagae R, Damantec JH, Quantitative age-related differences in human sublingual gland // Arch Oral Biol, 2006; 51:960 - 966

17. Ohsava K, Ushida M, Aiyama S, Three-dimensional observation of blood vesels supplying the gland proper and capsule of the mouse submandibular gland // Ann Anat, 2006; 188:61 - 67

18. Scott J, Degenerative changes in the histology of the human submandibular salivary gland occuring with age // J Biol Buccales, 1977; 5:311 - 319

19. Scott J, Qualitative and quantitative observations on the histology of human labial salivary glands obtained post mortem // J Biol Buccale, 1980; 8:187 200

20. Scott J, Quantitative age changes in the histological structure of human submandibular salivary glands // Arch Oral Biol, 1977; 22:221 - 225

21. Scott $J$, The incidence of focal chronic inflammatory changes in human submandibular salivary glands // J Oral Pathol, 1976; 5:334 - 346

22. Standish SM, Shafer WG, Serial histologic effects of rat submaxillary and sublingual salivary gland duct and blood vessel ligation // J Dent Res, 1957; 36:866 879

23. Takahashi Y, Kurabuchi S, Aiyama S, Histological changes in the mouse submandibular gland subjected to parasympathetic nerve block or ischemia: comparison between chorda tympani resection and trophic vessel transection // SHIGAKU (Odontology) 1999; 86:826 - 841

24. Vered M, Buchner A, Haimovici E, Hiss Y, Dayan D, Focal lymphocytic infiltration in aging human palatal salivary glands: a comparative study with labial salivary glands // J Oral Pathol Med, 2001; 30:710-716

25. Waterhouse JP, Chisholm DM, Winter RB, Paterand M, Yale RS, Replace-ment of functional parenchymal cells by fat and connective tissue in human submandibular salivary glands: age related changes // J Oral Pathol, 1973; 14:16 - 27

26. Wilson DF, Histology of the salivary glands // In Textbook of Oral and Maxillofacial Anatomy, Histology and Embryology edited by S.R.Prabhu, Oxford: 2006;169 - 179

\section{ACKNOWLEDGEMENTS}

This study was supported by European Social Fund. 


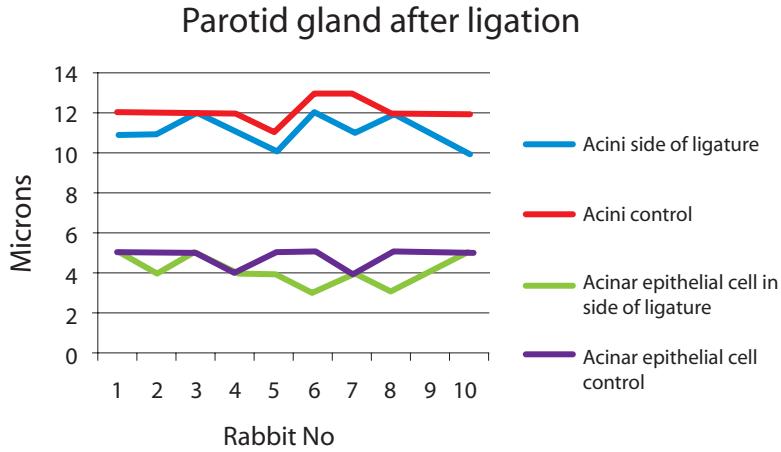

Fig. 1. Diameter of parotid gland acini and acinar epithelial cells 4 weeks after ipsilateral common carotid artery ligation

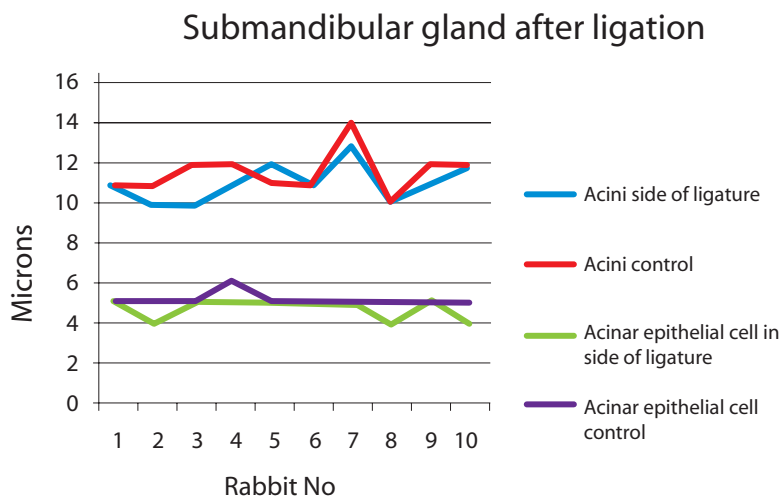

Fig. 2. Diameter of submandibular gland acini and acinar epithelial cells 4 weeks after ipsilateral common carotid artery ligation

Buccal gland after ligaton

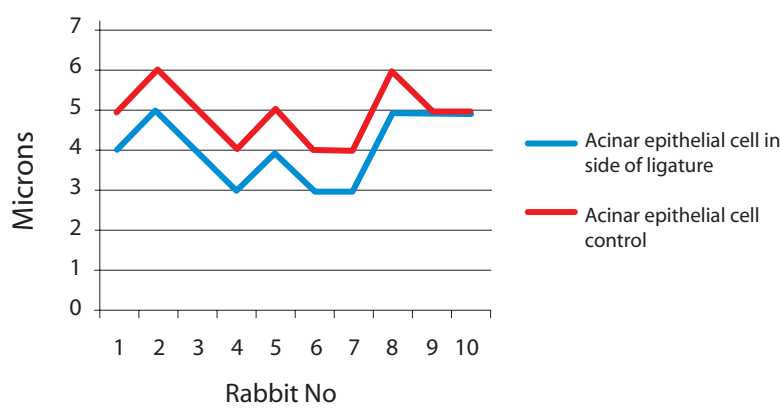

Fig. 3. Diameter of buccal gland acinar epithelial cells 4 weeks after ipsilateral common carotid artery ligation
Submandibular gland after revascularization

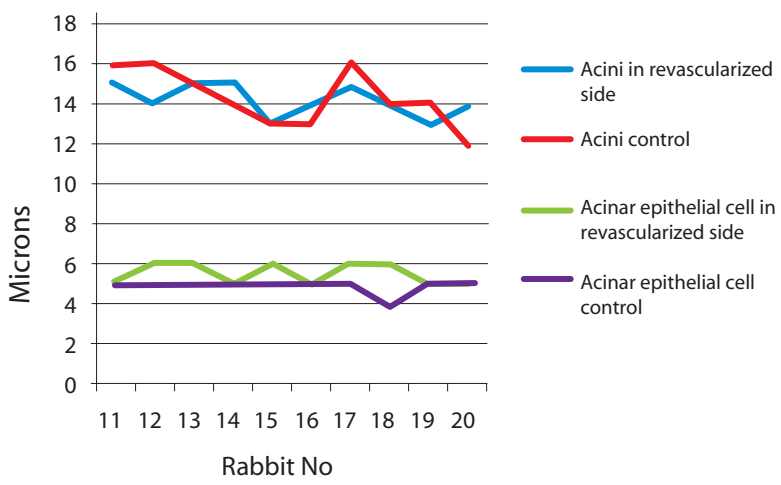

Fig. 4. Diameter of submandibular gland acini and acinar epithelial cells 4 weeks after ipsilateral common carotid artery revascularization

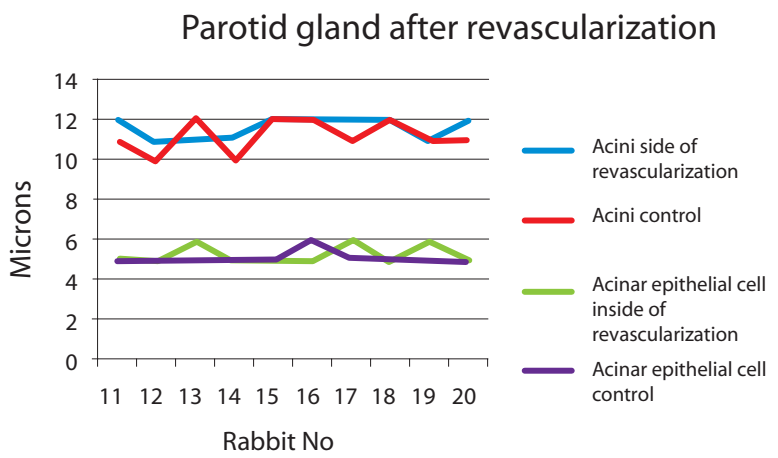

Fig. 5. Diameter of parotid gland acini and acinar epithelial cells 4 weeks after ipsilateral common carotid artery revascularization

\section{Buccal gland afterrevascularization}

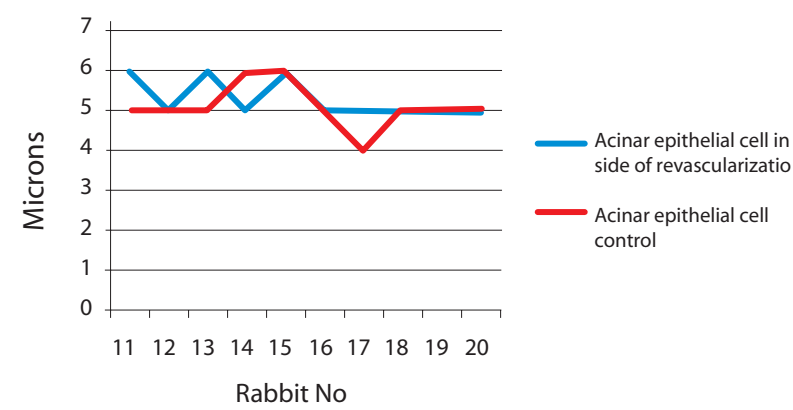

Fig. 6. Diameter of buccal gland acinar epithelial cells 4 weeks after ipsilateral common carotid artery revascularization 


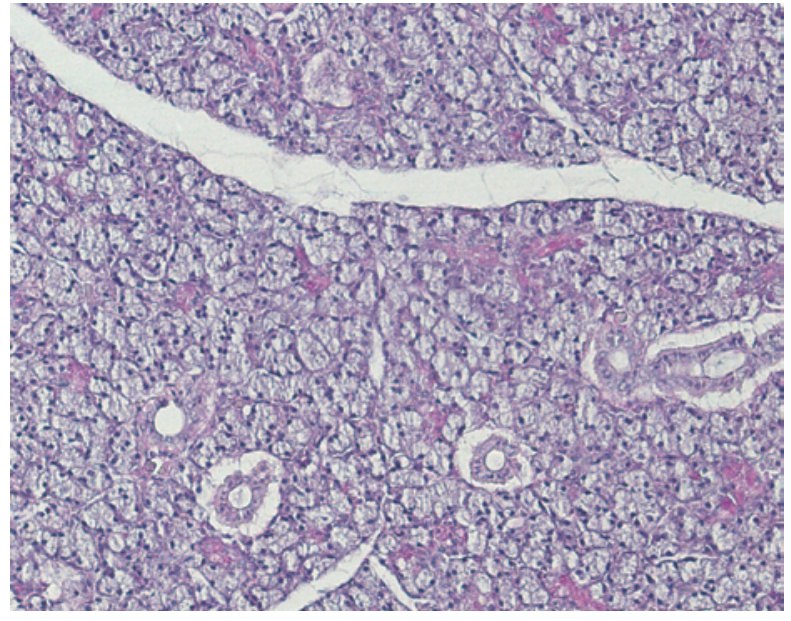

Fig. 7. Submandibular gland control side after ischemia, x 200

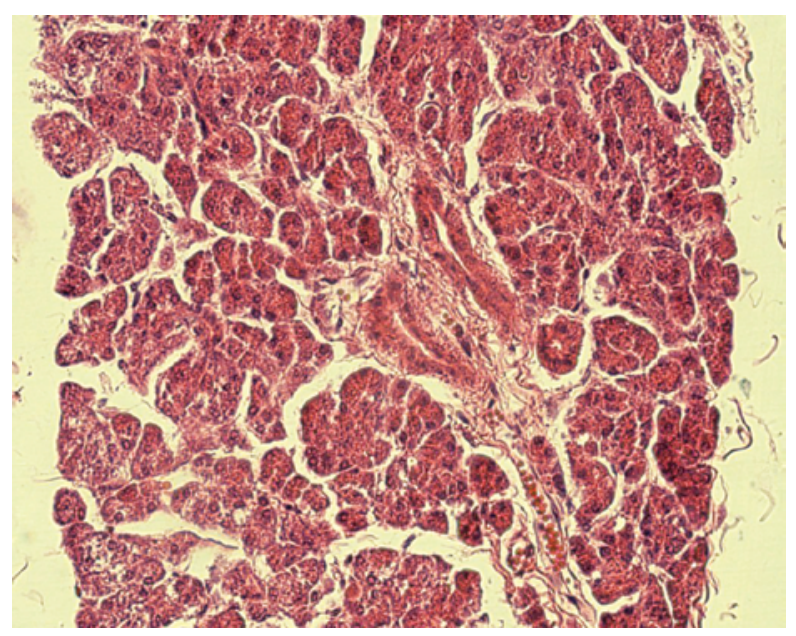

Fig. 8. Parotid gland test side after ischemia, $x 400$

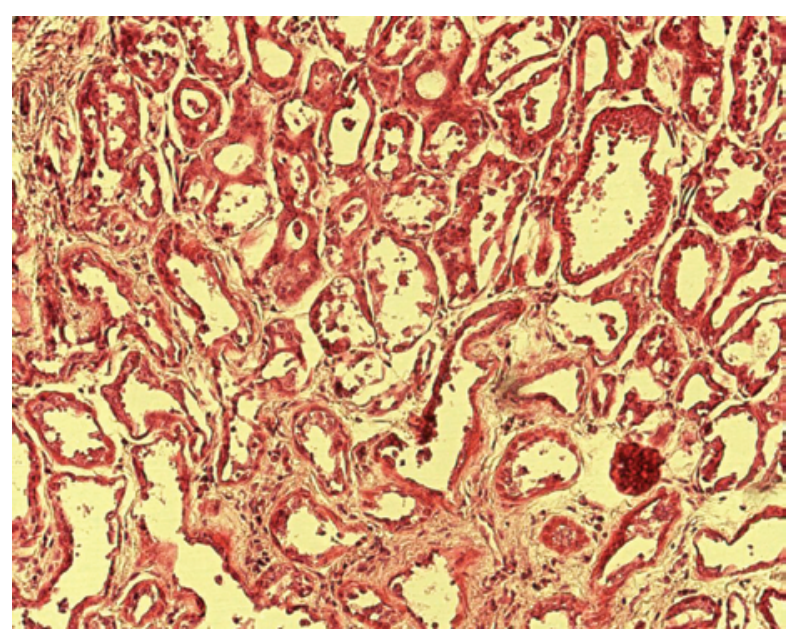

Fig. 9. Buccal gland test side after ischemia, x 200

\section{Address:}

Kaspars Stamers

Department of Oral and Maxillofacial Surgery

Riga Stradins University, Institute of Stomatology

20 Dzirciema Street,

Riga, Latvia, LV-1007

E-mail - STAMERSONS@INBOX.LV 